\title{
Crustal structure of the Volgo-Uralian subcraton revealed by inverse and forward gravity modeling
}

\author{
Igor Ognev ${ }^{1}$, Jörg Ebbing ${ }^{2}$, Peter Haas ${ }^{2}$
}

${ }^{1}$ Institute of Geology and Petroleum Technologies, Kazan Federal University, 4/5 Kremlyovskaya street, Kazan 420008, 5 Russia

${ }^{2}$ Department of Geosciences, Kiel University, Otto-Hahn Platz 1, Kiel, D-24118, Germany

Correspondence to: Igor Ognev (ognev.igor94@gmail.com)

\begin{abstract}
Volgo-Uralia is a Neoarchean easternmost part of the East European craton. Recent seismic studies of the VolgoUralian region provided new insights into the crustal structure of this area. In this study, we combine satellite gravity and seismic data in a common workflow to perform a complex study of Volgo-Uralian crustal structure which is useful for further basin analysis of the area. In this light, a new crustal model of the Volgo-Uralian subcraton is presented from a step-wise approach: (1) inverse gravity modeling followed by (2) 3D forward gravity modeling.
\end{abstract}

First, inversion of satellite gravity gradient data was applied to determine the Moho depth for the area. Density contrasts between crust and mantle were varied laterally according to the tectonic units present in the region, and the model is constrained

15 by the available active seismic data.

The Moho discontinuity obtained from the gravity inversion was consequently modified and complemented in order to define a complete 3D crustal model by adding information on the sedimentary cover, upper crust, lower crust, and lithospheric mantle layers in the process of forward gravity modeling where both seismic and gravity constraints were respected. The obtained model shows crustal thickness variations from 32 to more than $55 \mathrm{~km}$ in certain areas. The thinnest crust with a thickness

20 below $40 \mathrm{~km}$ is found beneath the Pericaspian basin, which is covered by a thick sedimentary layer. The thickest crust is located underneath the Ural Mountains as well as in the center of the Volga-Uralian subcraton. In both areas the crustal thickness exceeds $50 \mathrm{~km}$. At the same time, initial forward gravity modeling has shown a gravity misfit of ca. $95 \mathrm{mGal}$ between the measured Bouguer gravity anomaly and the forward calculated gravity field in the central area of the Volga-Uralian subcraton. This misfit was interpreted and modeled as a high-density lower crust which possibly represents underplated material.

Our preferred crustal model of the Volga-Uralian subcraton respects the gravity and seismic constraints and reflects the main geological features of the region with Moho thickening in the cratons and under the Ural Mountains and thinning along the Paleoproterozoic rifts, Pericaspian sedimentary basin, and Pre-Urals foredeep. 
https://doi.org/10.5194/se-2021-98

Preprint. Discussion started: 17 August 2021

(c) Author(s) 2021. CC BY 4.0 License.

(c) (i)

\section{Introduction}

30 Crustal thickness and thicknesses of individual layers of the Earth's crust play a determining role in estimating the thermal field due to the relative abundance of the radioactive heat-producing elements in the crust (Beardsmore and Cull, 2001; Bouman et al., 2015; Hantschel and Kauerauf, 2009). This fact is particularly important in the case of the Volgo-Uralian subcraton as it is located underneath the Volga-Ural oil and gas-bearing province with several giant oil fields, where the maturity of the organic-rich rocks is considered to be tightly related to the temperature distribution in the crust (Khasanov et

35 al., 2016; Khristoforova et al., 2008). Therefore, having the knowledge of the Volgo-Uralian crustal structure is the first major step into further basin analysis of the area.

Volgo-Uralia is a large easternmost segment of the East European craton (EEC). It has been regarded as a separate subcraton along with Sarmatia and Fennoscandia starting from the end of the 20th century (Gorbatschev and Bogdanova, 1993). The Volgo-Uralian part of the EEC is mostly embedded in the East European (Russian) platform, and like the rest of the platform,

40 it does not show any significant topographic variations. It represents a flat area with absolute relief heights ranging from 50 to $250 \mathrm{~m}$ for most of the territory. Despite the unremarkable topography of Volgo-Uralia, the same does not hold for its lithospheric structure. Different crustal layers of the subcraton show thickness variations in the order of several tens of km (Artemieva, 2007; Artemieva and Thybo, 2013; Mints et al., 2015).

Several recent crustal models which encompass Volgo-Uralia are based for the most part on regional seismic investigations

45 (Artemieva and Thybo, 2013; Mints et al., 2015). Nevertheless, the gravitational field can also be an essential constraint for the Moho depth especially on the areas devoid of seismic data or with moderate seismic coverage (e.g. Aitken et al., 2013; Steffen et al., 2017). Nowadays, due to the advent of satellite gravimetry, it is possible to obtain gravity field maps with uniform coverage for almost any desired territory of the Earth with a resolution sufficient for regional Moho depth investigation (Bouman et al., 2015).

50 In this paper, we present a novel model of the Volga-Uralian subcraton's crustal structure based on inverse and forward 3D gravity modeling with seismic constraints. The main objective of the study is to build a regional crustal model of Volgo-Uralia which in turn can serve as a basis for the further geothermal modeling of the area. In this paper, Section 2 is devoted to a brief overview of the tectonic setting and history of the region. Section 3 gives an outlook on the methods and datasets that were used in the study. All the used datasets are outlined in section 3.1. Applied gravity inversion methods are discussed in Section

55 3.2, which is followed by Section 3.3 where the process of forward gravity modeling is described. The main results of the inverse and forward gravity modeling as well as the final crustal model of Volgo-Uralia and its comparison to other existing models are presented and discussed in Section 4.

\section{Tectonic setting of the Volgo-Uralian subcraton}

The preset-day tectonic setting of the Volgo-Uralian region has formed throughout the assembly of the EEC. It started with the collision of Volgo-Uralia and Sarmatia at 2.1-2.05 Ga which led to the creation of a megacontinent Volgo-Sarmatia with 
https://doi.org/10.5194/se-2021-98

Preprint. Discussion started: 17 August 2021

(c) Author(s) 2021. CC BY 4.0 License.

(c) (1)

Volga-Don collisional orogen developed on the junction zone between the two segments (Bogdanova et al., 2016). Later, during Meso- and Neoproterozoic times, the Pachelma aulacogen was formed along the Volgo-Uralia-Sarmatia border which in combination with the Pericaspian sedimentary basin now delineates the south-western border of the Volgo-Uralian subcraton (Fig. 1). After several hundred million years at $1.8 \mathrm{Ga}$, the collision between Volgo-Sarmatia and Fennoscandia commenced.

65 It ended during the formation of the Rodinia supercontinent at $1.0 \mathrm{Ga}$. The suture intervening Fennoscandia and VolgoSarmatia was the place of Central-Russian orogeny growth which then was reworked into Central-Russian and Volyn-Orcha rifts. At present, the Central-Russia rift system represents the north-western border of the Volgo-Uralian subcraton (Bogdanova et al., 2016).

On the east, Volgo-Uralia is separated from the West Siberian basin by the young Late Paleozoic Uralide orogen and Late 70 Proterozoic Timanide orogen (Artemieva, 2007). 


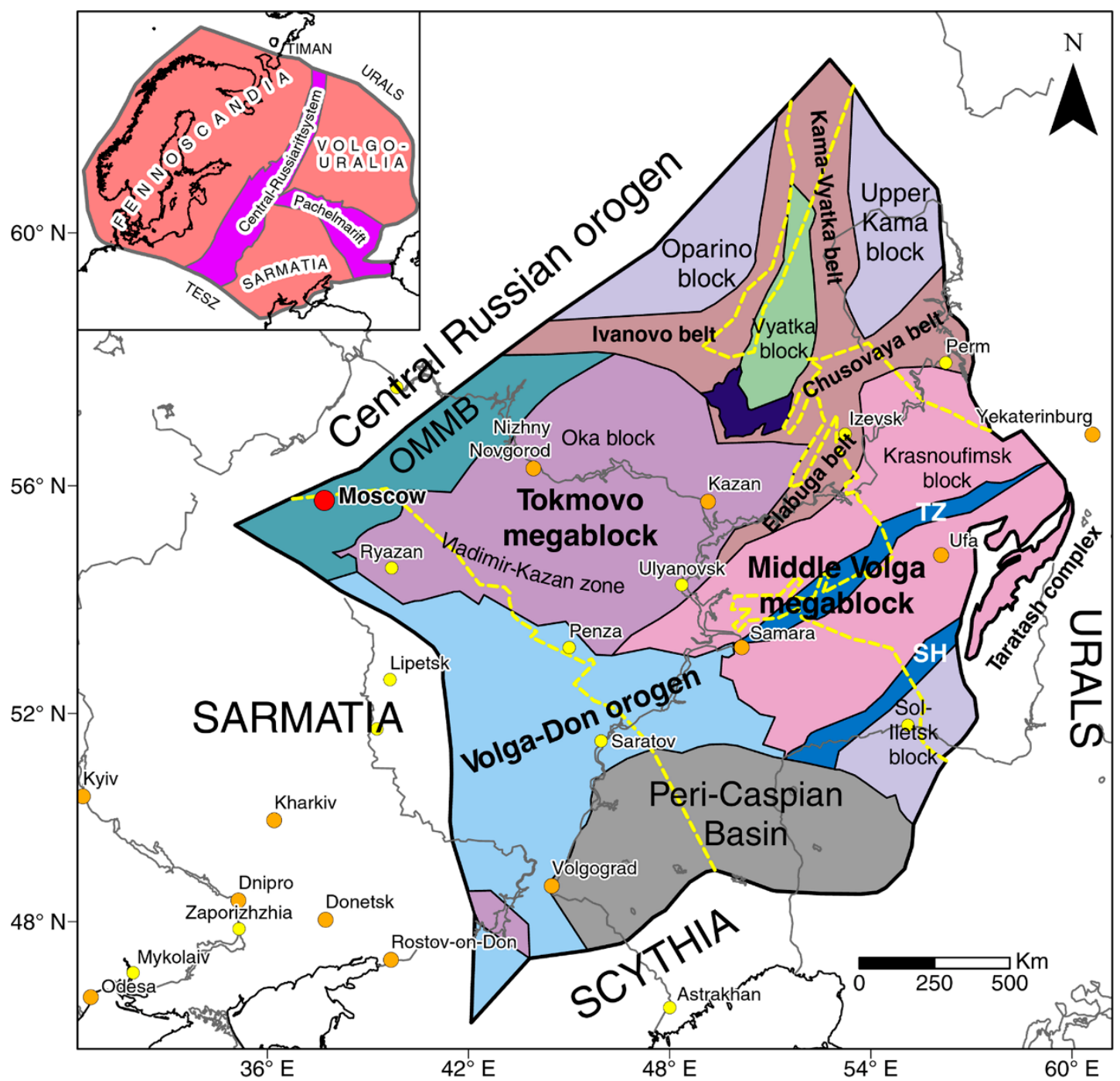

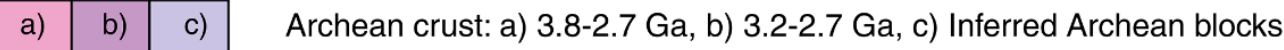

Archean and Paleoproterozoic crust reworked in deformation belts at 2.0-1.9 Ga

Tuymaza (TZ) and Sharlyk (SH) deformation zones

\begin{tabular}{l|l|l|l|l|l|l} 
a) & b) & c) Paleoproterozoic crust: a) 2.3-2.1 Ga, b) 2.0-1.95 Ga, c) $<2.1 \mathrm{Ga}$
\end{tabular}

Ultramafic and mafic intrusions of ca. 2.4-2.0 Ga

Peri-Caspian Basin which includes Mesoproterozoic to Phanerozoic successions
Volgo-Uralia boundary $\begin{aligned} & \text { Tectonic boundaries } \\ & \text { of Volgo-Uralian crustal } \\ & \text { blocks }\end{aligned} \quad \begin{aligned} & \text { Main aulacogens' } \\ & \text { boundaries }(1.6-1.0 \mathrm{Ga})\end{aligned}$

Figure 1: Main tectonic elements of Volgo-Uralian subcraton (redrawn after Bogdanova et al., 2016). 
https://doi.org/10.5194/se-2021-98

Preprint. Discussion started: 17 August 2021

(c) Author(s) 2021. CC BY 4.0 License.

\section{(c) (1)}

In contrast to Sarmatian and Fennoscandian segments of the EEC, Volgo-Uralia except for the Taratash complex is completely covered by Neoproterozoic to Phanerozoic sediments which prevent direct studies of the rocks from the outcrops. Nonetheless, extensive drilling activity due to the high hydrocarbon potential of the region has provided numerous core samples of the basement which are telling the composition and the age of the Volgo-Uralian segment (e.g. Bogdanova et al., 2010).

For the most part, Volgo-Uralia is comprised of Archean continental crust, which is concentrated in large blocks surrounded by Paleoproterozoic mobile belts. The two most prominent blocks of Archean crust are the Meso- to Neoarchean Tokmovo megablock and Paleo- to Neoarchean Middle-Volga megablock which in the literature are often associated with the so-called “ovoid" patterns of geophysical anomalies (Bogdanova et al., 2016; Mints et al., 2010). These blocks are dismembered by Elabuga and Chusovaya deformation belts and correspond to relative crystalline basement highs. The sedimentary thickness of the Archean part of Volgo-Uralia rarely exceeds $2 \mathrm{~km}$. Local increases in thicknesses of sedimentary cover are observed in Paleoproterozoic aulacogenic and graben-like structures and can reach up to 5-10 km (Shargorodskiy et al., 2004). A regional trend of a considerable increase of sedimentary cover thickness is observed towards the Ural Mountains in the system of KamaBelsk rifts (Fig. S1 in the supplement). Especially thick sedimentary sequences are located to the south of the Volgo-Uralian subcraton where it reaches the Pericaspian depression. There sediments have accumulated in successions with a thickness of more than $20 \mathrm{~km}$ (Artemieva and Thybo, 2013).

In terms of the crustal structure, Volgo-Uralia is generally a realm of thick and dense crust principally in its Archean part

90 (Bogdanova et al., 2016). Locally crustal thickness can reach depths as high as $60 \mathrm{~km}$ in the center of the craton. The evidence of such thick crust in Volgo-Uralia is found in the recent seismic survey of Tatarstan where several crustal roots plunging to depths of more than $55 \mathrm{~km}$ are disclosed on the TATSEIS-2003 reflection profile (Artemieva and Thybo, 2013; Trofimov, 2006). Relatively shallow Moho was observed seismically within the Central Russian and Pachelma Paleoproterozoic rifts representing suture zones between individual segments of the EEC. Another region with documented thin crust is the

95 Pericaspian sedimentary basin where the crust is thinning down to $32-36 \mathrm{~km}$ (Artemieva, 2007). The recent seismic model EUNAseis suggests that Volgo-Uralia has a thick upper crust (with thickness of more than $30 \mathrm{~km}$ in some places) which is associated with the above mentioned crustal roots (Artemieva and Thybo, 2013). Earlier findings reveal the correlation between the thicknesses of crustal layers and the tectonic history of the region. That is to say, there is the thickening of the upper crust along the Central-Russia Paleoproterozoic rift system and the thickening of the lower crust beneath the Archean blocks of the subcraton (Artemieva, 2007).

\section{Data and methods}

The work was subdivided into two main steps to build a crustal model of Volgo-Uralia:

1. Gravity field inversion where a preliminary estimate of the Moho depth boundary is obtained.

2. $3 \mathrm{D}$ forward gravity modeling where an extensive crustal model of Volgo-Uralia is built. The model incorporates 105 sedimentary, crustal, lithospheric mantle, and asthenospheric layers along with the previously obtained Moho interface. 
Before the inversion, the gravity data was preprocessed by calculating and subtracting the sedimentary cover effect from the Bouguer gravity anomaly. The schematic workflow of the study is shown in Fig. 2.

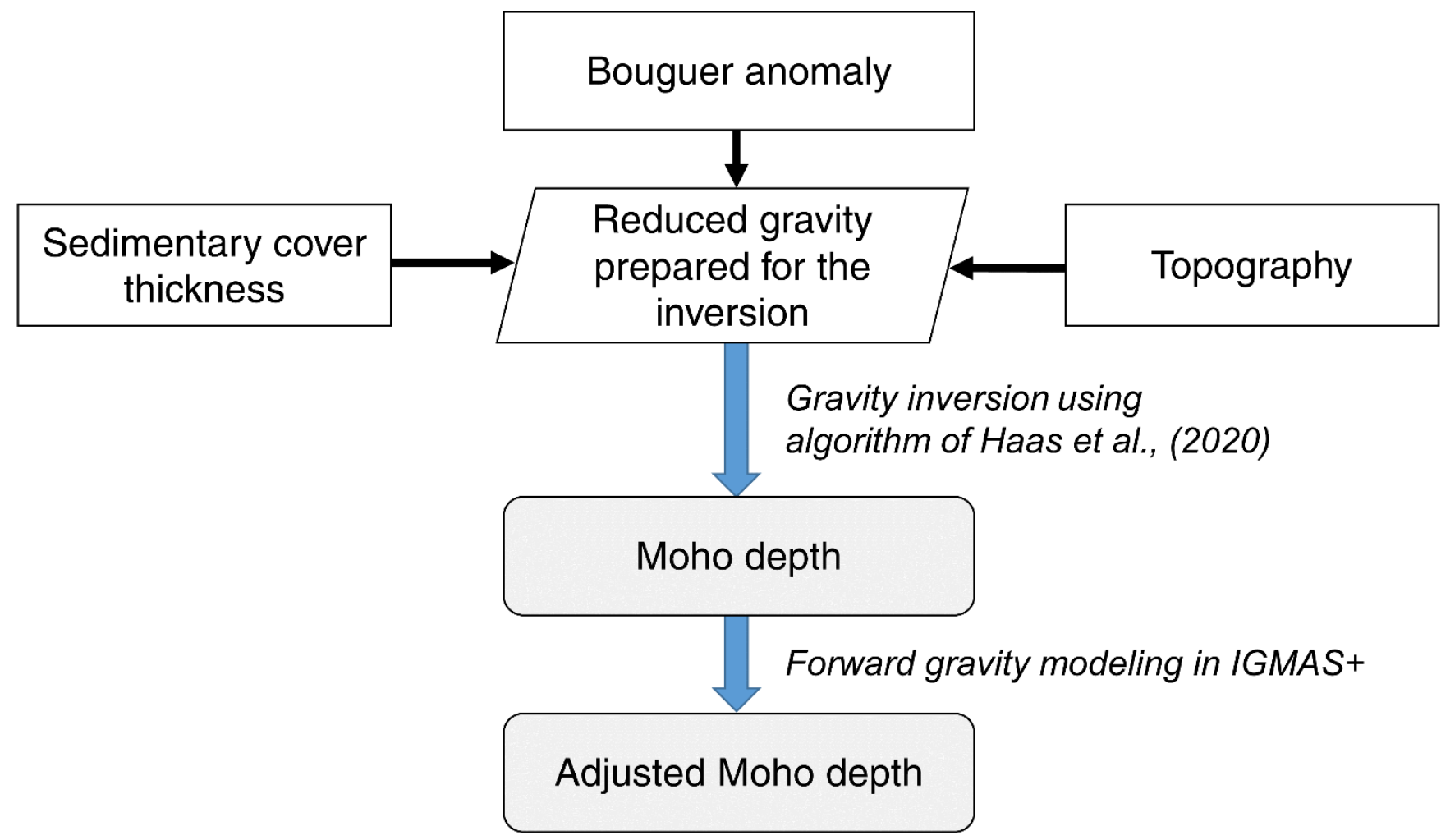

110 Figure 2: Schematic workflow of the study. The initial step is to prepare the gravity data for the inversion by subtracting the sedimentary cover effect from the Bouguer gravity anomaly. Only then gravity inversion and subsequent forward gravity modeling can follow.

\subsection{Data description}

115 For a successful crustal model construction four main groups of data were utilized:

- Seismic data used to constrain the Moho during the inverse and forward gravity modeling;

- Gravity data used as a main source of information for gravity inversion and one of the constraints in the forward modeling;

- Structural data, used for inverse and forward gravity modeling;

- Petrophysical data, which were implemented in the forward gravity modeling process.

A summary of the used datasets with their sources is given in Table 1. 
https://doi.org/10.5194/se-2021-98

Preprint. Discussion started: 17 August 2021

(c) Author(s) 2021. CC BY 4.0 License.

(c) (1)

Table 1. Summary of datasets used in the modeling

\begin{tabular}{ll}
\hline Data & Reference \\
\hline Seismic data & \\
USGS global seismic catalog & Chulick et al. (2013) \\
TATSEIS-2003 reflection profile & Trofimov (2006) \\
URSEIS-95 reflection profile & Tryggvason et al. (2001), Puchkov (2010) \\
UWARS reflection profile & Thouvenot et al. (1995) \\
ESRU reflection profile & Brown et al. (2002), Rybalka et al. (2006) \\
Gravity data & \\
GOCE gravity gradients & Bouman et al. (2016) \\
XGM2019e gravity field model & Zingerle et al. (2019) \\
Structural data & \\
ETOPO1 relief & Amante and Eakins (2009) \\
EUNAseis sedimentary thickness & Artemieva and Thybo (2013) \\
LAB interface & Artemieva (2019) \\
Petrophysical data & \\
Constraints on sedimentary, crustal, and & mantle \\
densities & Artemieva (2007) \\
\hline
\end{tabular}

\section{3.1.1 Seismic data}

Seismic estimations of crustal thickness play a crucial role in gravity modeling as they are the main constraint on the crustal structure. We used seismic data within the studied region from the USGS global seismic catalog (Chulick et al., 2013) which has the information on crustal thickness from the main reflection and refraction surveys performed on the Russian platform mostly during the Soviet period. We also added data coming from recent regional seismic surveys made at the end of the $20^{\text {th }}$ 130 and beginning of the 21 st century on the Volgo-Uralian craton which were not originally included in the catalog. These are TATSEIS-2003 geotraverse (Trofimov, 2006) going through the center of Volgo-Uralia, and URSEIS-95, ESRU, and UWARS profiles which mark the crustal structure on the eastern border of Volgo-Uralia crossing the Ural Mountains (Brown et al., 2002; Thouvenot et al., 1995; Tryggvason et al., 2001). Moho depth estimations from seismic databases used in the study are shown in Fig. 3. 


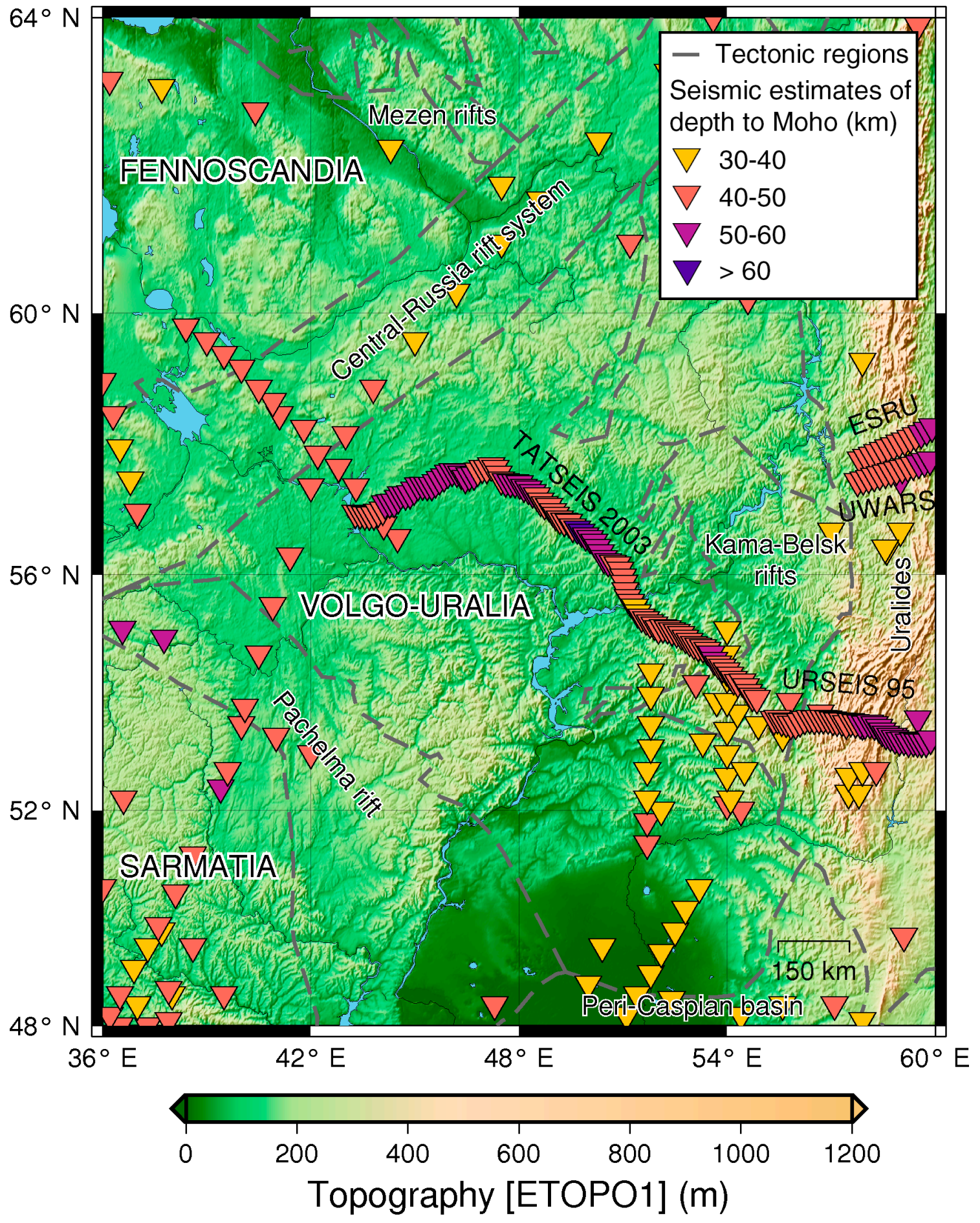

Figure 3: Framework of the studied region with the seismic constraints on Moho depth. Relief is taken from the ETOPO1 model (Amante and Eakins, 2009). Seismic estimates of depth to Moho are used according to USGS seismic catalog (Chulick et al., 2013), TATSEIS-2003 (Trofimov, 2006), URSEIS-95 (Puchkov, 2010; Tryggvason et al., 2001), ESRU (Brown et al., 2002; Rybalka et al., 2006), and UWARS profiles (Thouvenot et al., 1995). 
https://doi.org/10.5194/se-2021-98

Preprint. Discussion started: 17 August 2021

(c) Author(s) 2021. CC BY 4.0 License.

(c) (i)

\subsubsection{Gravity data}

In the present workflow, the gravity field is the main source of information used for crustal thickness estimation in the area devoid of seismic constraints. It is shown that GOCE gravity gradients on satellite height are sensitive to interfaces with large density contrasts like Moho (Bouman et al., 2015). That is why, we utilized GOCE vertical gravity gradients grids on satellite

145 height in the process of gravity inversion (Bouman et al., 2016). In addition, topographically corrected GOCE vertical gravity gradients at $225 \mathrm{~km}$ altitude and surface simple Bouguer gravity anomaly from the global gravitational model XGM2019e were utilized as constraints for the forward gravity modeling (Zingerle et al., 2019).

\subsubsection{Structural data}

Several complementary structural datasets were used in the modeling. Surface relief and sedimentary cover thickness are necessary to subtract the gravitational effect of sediments from the Bouguer gravity field and prepare the gravity data for the inversion (Section 3.2). For that purpose, we took ETOPO 1 topographic model (Amante and Eakins, 2009) and sedimentary cover structure inferred from the EUNAseis seismic model for Moho and crustal structure in Europe, Greenland, and the North Atlantic region (Artemieva and Thybo, 2013).

Knowing the structure of the Earth's lithosphere can also be useful in the forward gravity modeling process as lithosphere-

155 asthenosphere boundary (LAB) is an interface with a density contrast that affects the gravity field. Here, we added the LAB boundary calculated from the concept of thermal isostasy by Artemieva (2019). Being an isothermal boundary, it does not only serve just as additional density contrast but also provides information about the thermal state of the lithospheric mantle.

\subsubsection{Petrophysical data}

The main petrophysical parameter which is involved in operations with gravity field is density. The density model used in the

160 study is given in table 2. Densities of sediments were described by the function of exponential growth of density with depth obtained for the EEC (Artemieva, 2007). Densities of the upper and lower crust were taken based on the seismic estimates of the densities of the CRUST 1.0 model (Laske et al., 2013).

Table 2. Density model used in the study

\begin{tabular}{ll}
\hline Layer & Density, $\mathrm{kg} \mathrm{m}^{-3}$ \\
\hline Sedimentary cover & $2430 \times \mathrm{z}^{0.045 *}$ \\
Upper crust & 2750 \\
Lower crust & 2900 \\
Upper mantle & 3234 \\
Asthenosphere & 3224 \\
\hline
\end{tabular}

$* \mathrm{z}-1 / 2$ of the depth of sedimentary strata in $\mathrm{km}$ 
https://doi.org/10.5194/se-2021-98

Preprint. Discussion started: 17 August 2021

(c) Author(s) 2021. CC BY 4.0 License.

(c) (i)

Upper mantle density was calculated taking into account the contribution of thermal expansion to the density variations in the subcrustal lithosphere:

$\rho_{\text {min situ }}=\rho_{m}\left(1-\alpha \frac{T_{M}-T_{0}}{2}\right)$,

where $\rho_{m}$ - density of the lithospheric mantle at standard conditions, $\mathrm{kg} \mathrm{m}^{-3}$;

$T_{M}$ - temperature at the Moho boundary, ${ }^{\circ} \mathrm{C}$;

$T_{0}$ - temperature at the $\mathrm{LAB},{ }^{\circ} \mathrm{C}$;

$\alpha$ - thermal expansion coefficient, ${ }^{\circ} \mathrm{C}^{-1}$.

In this study, we consider that the Archean upper mantle is depleted in mafic components which lowers its density (Kaban et al., 2003). We take the density of the lithospheric mantle of EEC at room conditions of $3340 \mathrm{~kg} \mathrm{~m}^{-3}$ which corresponds to the

175 Paleoproterozoic-Archean age (Artemieva, 2007). The temperature at the Moho here is taken as $500{ }^{\circ} \mathrm{C}$ which is within the temperature range of Archean-Paleoproterozoic crust of EEC according to (Artemieva, 2007), and LAB temperature as 1400 ${ }^{\circ} \mathrm{C}$ as in our modeling the thermal LAB model of Artemieva (2019) was utilized. The thermal expansion coefficient is taken as $3.5 \times 10^{-5}{ }^{\circ} \mathrm{C}^{-1}$. Using these parameters, we obtained in situ density of the lithospheric mantle as $3234 \mathrm{~kg} \mathrm{~m}^{-3}$.

Slightly modifying Eq. (1) we can get in situ density of the asthenosphere:

$180 \rho_{\text {asth }}=\rho_{a}\left(1-\alpha T_{0}\right)$,

where $\rho_{a}$ - density of the asthenospheric mantle at standard conditions, which was taken as $3390 \mathrm{~kg} \mathrm{~m}^{-3}$ (Artemieva, 2007).

Asthenosphere density is equal to $3224 \mathrm{~kg} \mathrm{~m}^{-3}$. This leads to a quite negligible density contrast between the upper mantle and thermal lithosphere of $10 \mathrm{~kg} \mathrm{~m}^{-3}$ which will not have a big impact on the results of forward gravity modeling.

\subsection{Gravity field inversion}

185 3.2.1 Gravity data processing

Gravity field inversion requires initial gravity data to be refined to leave only the gravity signal of interest. In our case, the desired crustal interface is the Moho boundary. In order to obtain the signal that is produced primarily by the Moho undulations, several corrections to the gravity field must be applied. These necessarily would include correction for the latitude, free-air correction, and Bouguer correction. All the listed corrections are taken into account in the Bouguer gravity anomaly. We use

190 a simple Bouguer gravity gradient anomaly for the region with $2670 \mathrm{~kg} \mathrm{~m}^{-3}$ rock density and $1030 \mathrm{~kg} \mathrm{~m}^{-3}$ water density.

Another important interface with high-density contrast that causes anomalies on the satellite gravity field of the same wavelength as Moho does is the sediments-upper crust boundary (Steffen et al., 2017). Volgo-Uralia despite not having a large variation in sedimentary thickness in its cratonic part, is neighbored by Pre-Uralian through and Pericaspian basin where sedimentary successions can locally reach up to 10-20 km thickness (Artemieva and Thybo, 2013; Neprochnov et al., 1970). 
https://doi.org/10.5194/se-2021-98

Preprint. Discussion started: 17 August 2021

(c) Author(s) 2021. CC BY 4.0 License.

195 Therefore, it is essential to subtract the gravity effect of sediments from the Bouguer anomaly to get the refined gravity signal produced by the Moho interface:

$G_{R E F I N E D}=G_{B G}-G_{S E D}$,

where $G_{\text {REFINED }}$ - gravity gradient field prepared for the inversion which reflects mostly the Moho signal, eotvos;

$G_{B G}$ - Bouguer gravity gradient anomaly, eotvos;

$200 G_{S E D}$ - gravity gradient effect of sediments, eotvos.

As the modeled area is considerably large, we utilized tesseroids to account for the sphericity of the Earth (Uieda et al., 2016).

First, the depth of the sediments-upper crust interface was calculated on 1×1-degree mesh using the relief from ETOPO1 and sedimentary thickness from the EUNAseis model. Second, the sedimentary cover was subdivided into a number of tesseroids with lateral dimensions of $1 \times 1$ degree and vertical thickness of $1 \mathrm{~km}$. Third, each tesseroid was assigned a certain density 205 depending on its depth. The density-depth relationship for sedimentary cover for the East European platform was taken from (Artemieva, 2007):

$\rho=2430 \cdot z^{0.045}$,

where $z-1 / 2$ of the depth of sedimentary strata in $\mathrm{km}$.

Lastly, the gravity effect of sediments was calculated using Tesseroids Python package and it was consequently subtracted from the Bouguer gravity anomaly (Fig. 4). 
https://doi.org/10.5194/se-2021-98

Preprint. Discussion started: 17 August 2021

(c) Author(s) 2021. CC BY 4.0 License.
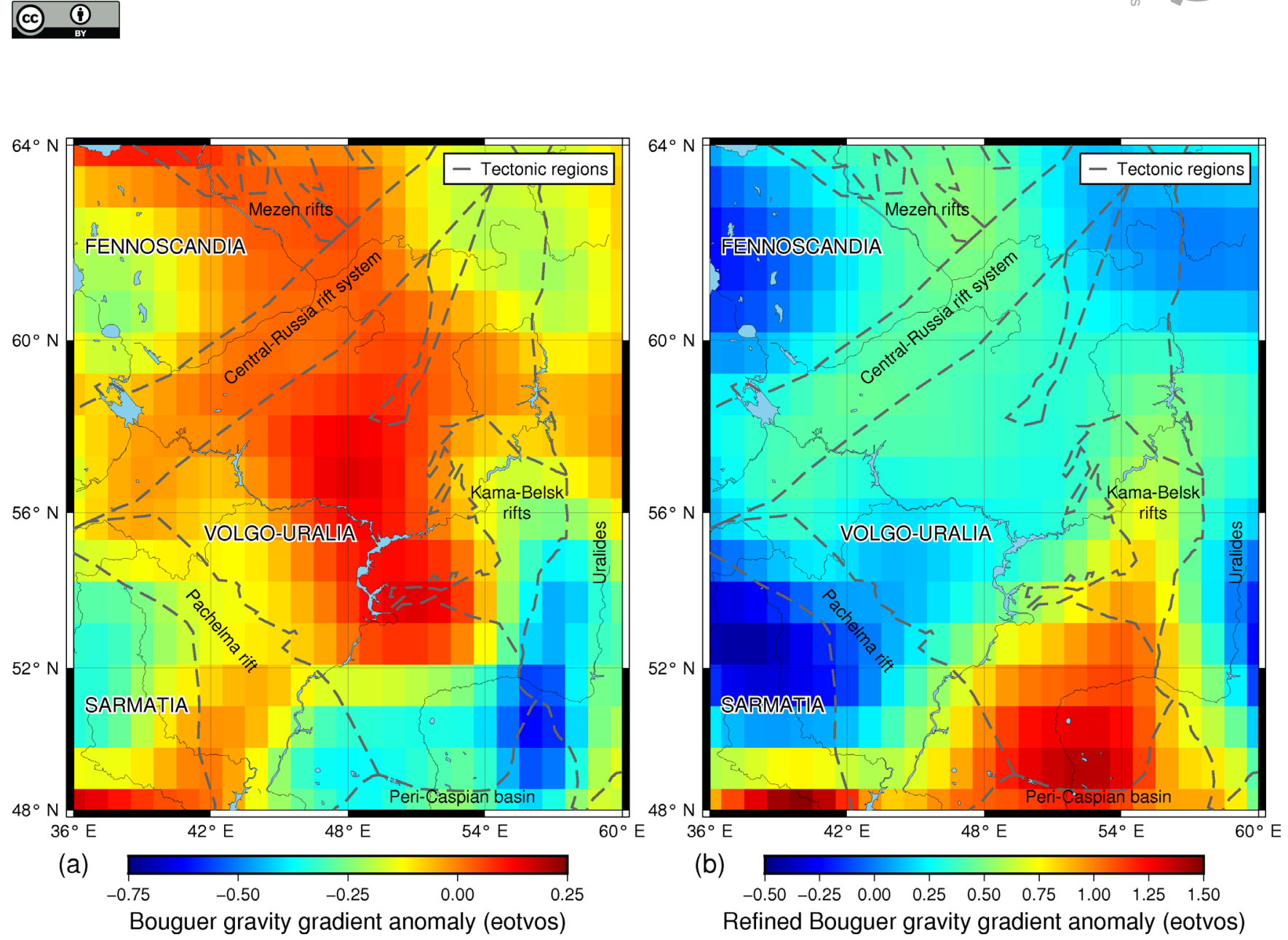

Figure 4: (a) Bouguer gravity gradient anomaly of Volgo-Uralia and (b) refined Bouguer gravity gradient anomaly corrected for the gravity effect of sediments. Dashed polygons represent tectonic regions used in gravity inversion.

\subsubsection{Gravity field inversion with laterally variable density contrast}

For the gravity field inversion, we followed a novel approach of Haas et al. (2020) which allows laterally variable crust-mantle density contrasts according to the tectonic regions present in the area of study. This approach solves the inverse problem with the Gauss-Newton algorithm, uses second-order Tikhonov regularization to ensure the stability of the solution, and requires

two hyperparameters for the inversion: reference Moho depth $z_{\text {ref }}$ and crust-mantle density contrast $\Delta \rho$ with the range of possible values. The algorithm iteratively sets each density contrast from the given range to the predefined tectonic regions, thus checking every possible combination of density contrasts' lateral distribution. Then it chooses the combination which gives the smallest RMS error between the Moho depth estimated through the inversion and Moho depth defined at the locations of available seismic measurements.

225 Although one can use any gravitational component for the inversion in the abovementioned algorithm, we stuck to the vertical gravity gradients as they are shown to be more sensitive to the Moho undulations than the other components (Bouman et al., 
https://doi.org/10.5194/se-2021-98

Preprint. Discussion started: 17 August 2021

(c) Author(s) 2021. CC BY 4.0 License.

(c) (i)

2016). Here for the purpose of tectonic regionalization, we take the main crustal provinces of Volgo-Uralia derived by (Bogdanova et al., 2016) which include the Archean cratonic continental crust and Paleoproterozoic mobile belts. We also distinguished Uralide orogen in a separate tectonic region because of its relatively young age and distinct crustal composition.

For the density contrasts, we chose a range of 350 to $550 \mathrm{~kg} \mathrm{~m}^{-3}$ and ran the code 10 times using different reference Moho depths ranging from 41 to $50 \mathrm{~km}$ with $1 \mathrm{~km}$ step. Finally, the Moho which fitted best to the seismic constraints was selected.

\subsection{Forward gravity modeling}

Gravity inversion was followed by the forward gravity modeling which was done in the IGMAS+ software (Götze and Lahmeyer, 1988; Schmidt et al., 2020). IGMAS+ is a geophysical package aimed at 3D numerical modeling, visualization, and interpretation of potential fields. It offers users to combine different sources of data in a common workflow such as seismic constraints, first, and second-order derivatives of gravitational potential, magnetic field data, and other geological and petrophysical information to produce the most accurate model of the Earth's interior.

At the beginning of the modeling, the study area was laterally extended by $2500 \mathrm{~km}$ to minimize edge effects. The vertical depth of the model was chosen to be $300 \mathrm{~km}$ in order to include all the interfaces along which the main density contrasts arise starting from the bottom of sediments and finishing with the LAB. The 3D model is constructed by triangulated polyhedrons in-between 67 vertical cross-sections, which are oriented in the west-east direction. The approximate distance separating the sections is $50 \mathrm{~km}$. IGMAS+ allows to forward calculate the gravity field from the model and cross-compare it with the measured values. The full process of forward gravity modeling of the current study can be described in 5 steps:

1. We imported seismic, structural, and gravity data in IGMAS+: (a) Moho interface derived previously from the gravity

245 inversion, (b) depth of the sediments from EUNAseis model (Artemieva and Thybo, 2013), (c) the depth of the LAB interface obtained from the thermal isostasy method (Artemieva, 2019), (d) Available seismic estimates of the Moho depth from USGS seismic catalog, TATSEIS, URSEIS, UWARS, and ESRU seismic profiles (Brown et al., 2002; Chulick et al., 2013; Thouvenot et al., 1995; Trofimov, 2006; Tryggvason et al., 2001), (e) Bouguer gravity anomaly from XGM2019e global gravity field model (Zingerle et al., 2019), (f) Bouguer gravity gradient anomaly calculated from the gravity gradient grids (Bouman et al., 2016). Additionally, we subdivided the crust into upper and lower parts with the initially horizontal interface. The densities of all the layers were set to the values according to Table 2. The sedimentary layer was discretized in a number of isometric voxels with a $1 \mathrm{~km}$ thickness. It allowed representing the exponential increase of sediments' densities with depth. 2. We adjusted the structure of gravity inverted Moho boundary where seismic data exposed different depths.

3. We forward calculated gravity and vertical gravity gradient's fields from the current model and observed a significant 255 gravity misfit of ca. $95 \mathrm{mGal}$ in the center of the Volgo-Uralian subcraton. This misfit was attributed to the underplated body with a relatively higher density located in the lower crust (see Section 4.2).

4. We estimated mass imbalance (surplus and deficit) in the area by isostatic calculations following the approach of Ebbing (2007) for the Scandinavian mountain chain: 
https://doi.org/10.5194/se-2021-98

Preprint. Discussion started: 17 August 2021

(c) Author(s) 2021. CC BY 4.0 License.

(c) (i)

$\rho_{\text {sed }} D_{\text {sed }}+\rho_{U C} D_{U C}+\rho_{L C} D_{L C}+\rho_{m} D_{m}+\rho_{a} D_{a}-\sum_{i=1}^{5} \rho_{\text {refi }} D_{\text {refi }}=\Delta L o a d / g$

260 Where $\rho$ and $D$ - densities and thicknesses of the sedimentary, upper crustal, lower crustal, lithospheric mantle, and asthenospheric layers of the IGMAS+ geological model;

$\rho_{\text {refi }}$ and $D_{\text {refi }}$ - densities and thicknesses of the reference model which are equal to the average values of these parameters used for the corresponding layers in the geological model.

The density of the underplated body was set to $3100 \mathrm{~kg} \mathrm{~m}^{-3}$. After we calculated the thickness of the lower crustal body associated with the underplating by dividing the obtained mass imbalance by the difference in densities of the lower crust and the assumed underplated body which is equal to $-200 \mathrm{~kg} \mathrm{~m}^{-3}$.

5. The last step was to modify the geometry of the layers to reach a good fit to the gravity data. Here Moho boundary and upper-lower crust interface were subjected to further modifications. The upper-lower crust interface was modified in order to both provide better gravity fit and resemble the patterns of the bottom of the "felsic-intermediate" crust from the EUNAseis model. Moho was modified in areas of no seismic constraints when it led to the enhancement of the gravity fit.

\section{Results and discussion}

As a result, a new crustal model of the Volga-Uralian subcraton was obtained throughout the gravity field inversion and forward gravity modeling.

\subsection{Results of the gravity inversion}

In the gravity inversion two hyperparameters, the reference depth and the density contrast were estimated such that the resulting gravity-inverted Moho showed the minimum RMSE with the seismic Moho depth estimates.

The reference depth which gave the best-fitted Moho to the seismic data was equal to $45 \mathrm{~km}$. Such a relatively deep estimate was obtained due to the fact that TATSEIS-2003 and URSEIS-95 seismic profiles provided a considerable fraction of Moho depths' measurements of more than $50 \mathrm{~km}$. In terms of the density contrast, Archean cratonic crust and Uralide orogen were assigned a density contrast of $550 \mathrm{~kg} \mathrm{~m}^{-3}$ and for the Paleoproterozoic belts it was equal to $400 \mathrm{~kg} \mathrm{~m}^{-3}$ (Fig. 5a). These values agree with previous findings of Eshagh et al. (2016) who used GOCE gravity gradients and determined that crust-mantle density contrast on the territory of Eurasia should be in the range of 400-600 $\mathrm{kg} \mathrm{m}^{-3}$. At the same time, other seismic-based studies suggest a slightly smaller density contrast around $300-400 \mathrm{~kg} \mathrm{~m}^{-3}$ for the tectonic settings similar to the ones of the modeled region (Chulick et al., 2002; Rabbel et al., 2013). This misfit can arise because gravity-based methods average the crustal and subcrustal densities and express their difference in one signal. Whereas, seismic-based methods restore densities for specific layers in the crust and the lithosphere and give a more targeted look at the contrast in densities between the lower crust and the lithospheric mantle. Our density model used in the forward gravity modeling gives a contrast of around $334 \mathrm{~kg}$ $\mathrm{m}^{-3}$ (Table 2) which is closer to the values coming from the seismic-based estimates. 
https://doi.org/10.5194/se-2021-98

Preprint. Discussion started: 17 August 2021

(c) Author(s) 2021. CC BY 4.0 License.

The obtained gravity-inverted Moho depth map generally respects the main known structural features of the crust in the region:

Moho thickens in the cratons and Uralides, and thins along the Paleoproterozoic rifts, Pre-Urals foredeep, and Pericaspian sedimentary basin (Fig. 5b).
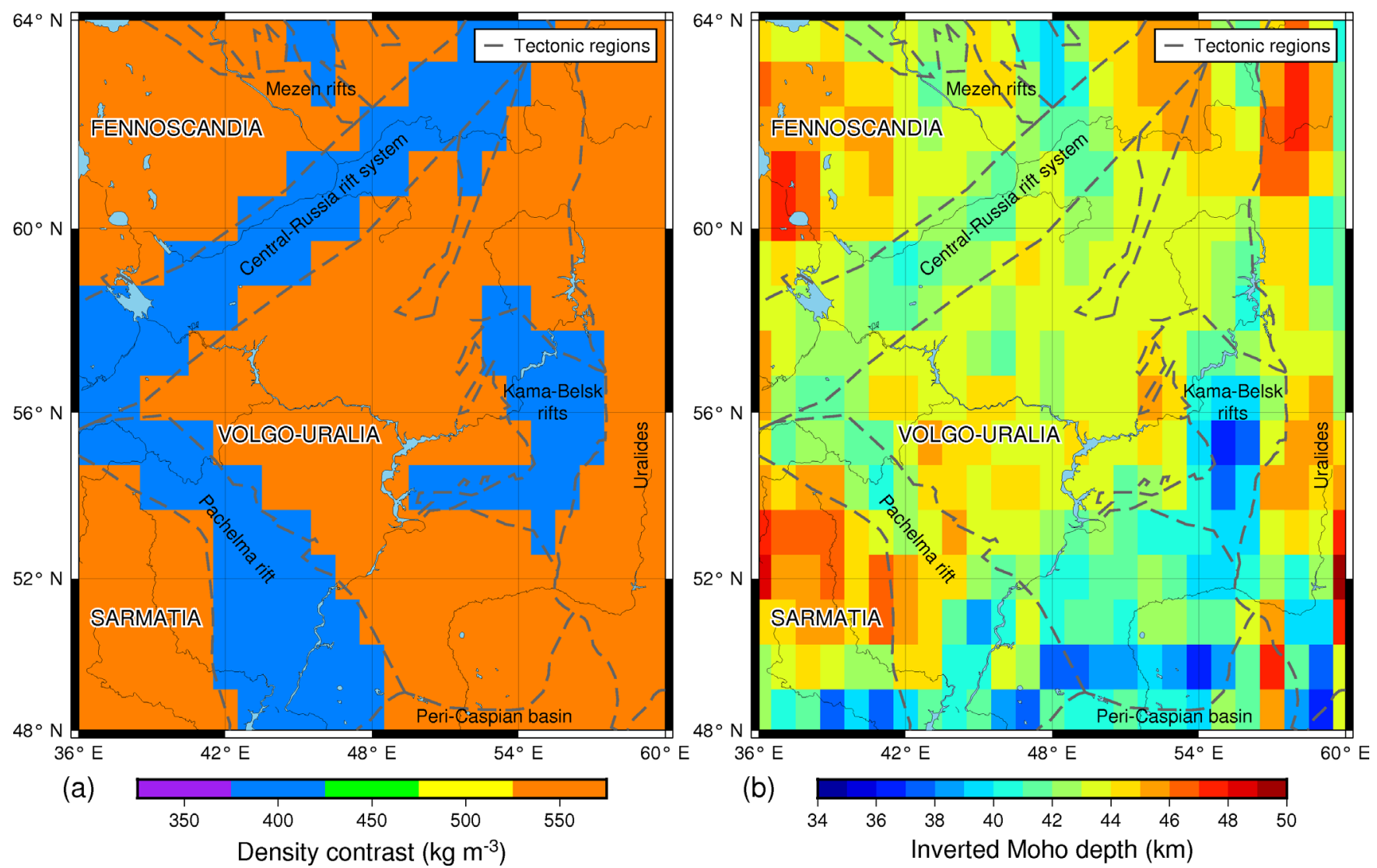

Figure 5: (a) Density contrasts determined by using the algorithm of Haas et al. (2020) and (b) the Moho depth obtained through the gravity field inversion. Reference depth is equal to $45 \mathrm{~km}$, crust-mantle density contrast of $400 \mathrm{~kg}^{-3}$ is assigned to Paleoproterozoic rifts, and of $550 \mathrm{~kg} \mathrm{m-3}$ to Archean cratons, and Uralide orogen.

\subsection{Results of the forward modeling}

The main product of the forward gravity modeling is the IGMAS+3D model of the Volgo-Uralian crustal structure. It includes

the updated Moho model along with the main crustal interfaces. The constructed IGMAS+ model has a standard deviation of measured and calculated gravity equal to $7.85 \mathrm{mGal}$ which corresponds to the correlation coefficient between the measured and calculated gravity of 0.91 (Fig. 6 a-c). For the gravity gradients, the standard deviation is equal to 0.12 eotvos and the correlation coefficient is 0.81 (Fig. 7 a-c). This can be considered as an acceptable gravity fit for a regional crustal study (e.g. Sobh et al. (2019). The general look of the IGMAS+3D model with the locations of vertical sections is given in Fig. 8. 
https://doi.org/10.5194/se-2021-98

Preprint. Discussion started: 17 August 2021

(c) Author(s) 2021. CC BY 4.0 License.

cC) (P)
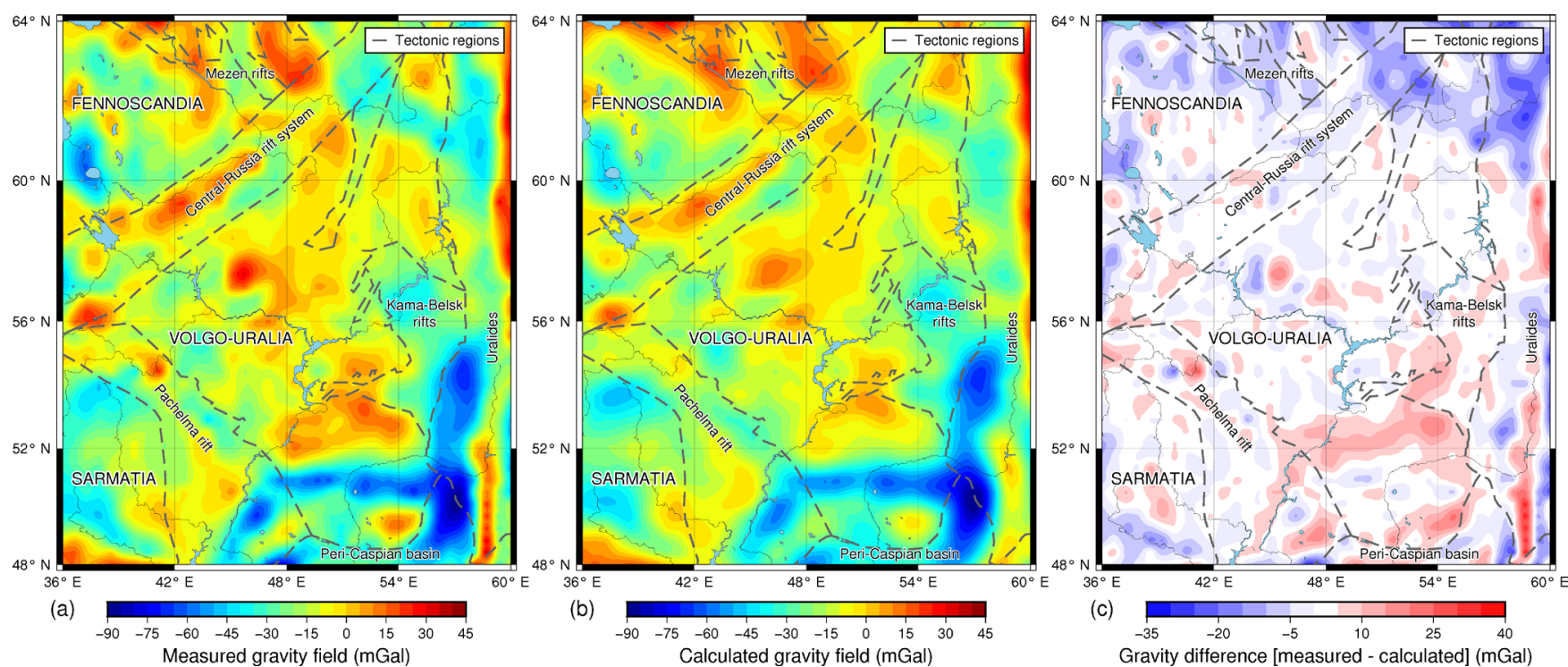

Figure 6: Comparison between measured and calculated gravity fields. (a) XGM2019e Bouguer gravity anomaly (Zingerle et al., 2019). (b) Calculated Bouguer gravity anomaly from IGMAS+ 3D model. (c) The difference between measured and calculated gravity fields.

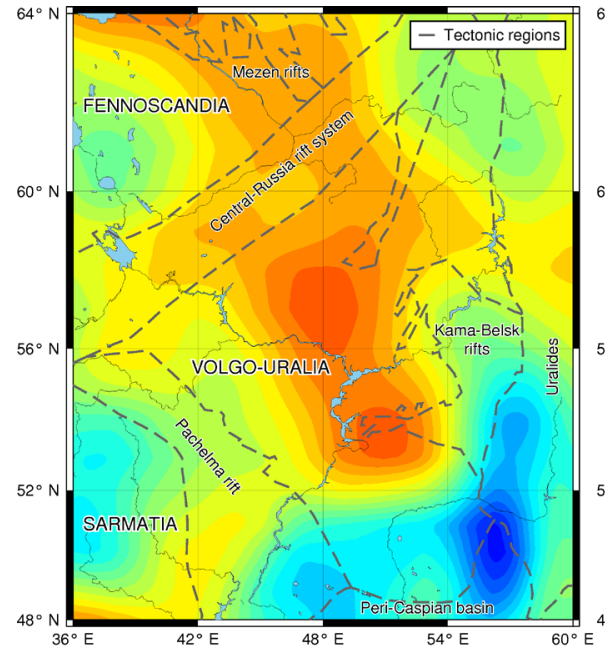

(a) $-0.90-0.75-0.60-0.45-0.30-0.15 \quad 0.00 \quad 0.15 \quad 0.30$
Measured gravity gradient field (eotvos)

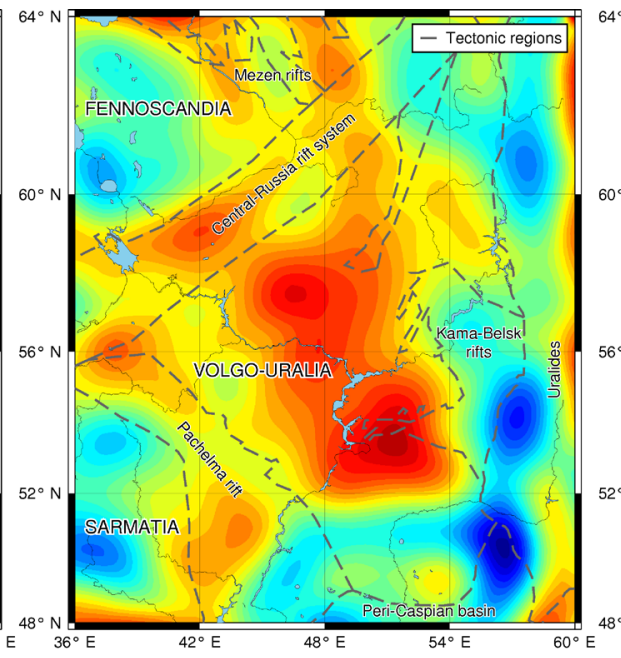

(b)

$-0.90-0.75-0.60-0.45-0.30-0.15 \quad 0.00 \quad 0.15 \quad 0.30$ Calculated gravity gradient field (eotvos)

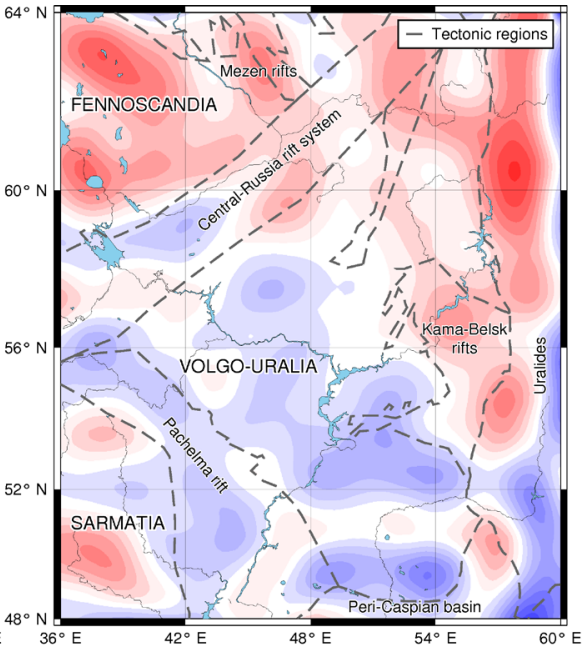

(c)

Gravity gradient difference [measured - calculated] (eotvos)

Figure 7: Comparison between measured and calculated gravity gradient fields. (a) GOCE vertical gravity gradient at 225 height (Bouman et al., 2016). (b) Calculated Bouguer gravity gradient anomaly from IGMAS+ 3D model. (c) The difference between measured and calculated gravity gradient fields. 


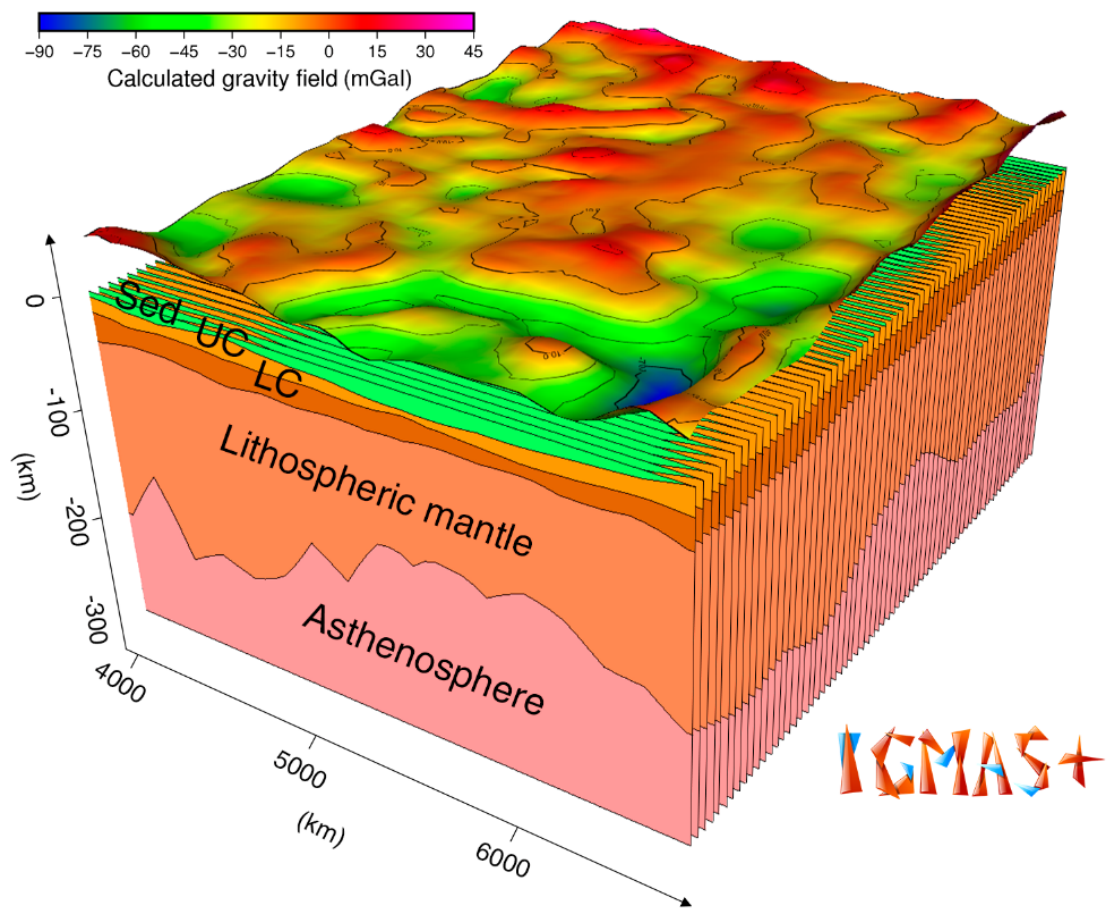

Figure 8: A 3D lithospheric model of Volgo-Uralia developed in IGMAS+ software. It consists of 67 vertical sections which gives a spatial resolution of approximately $50 \mathrm{~km}$. The model includes 5 layers: sediments (Sed), upper crust (UC), lower crust (LC), lithospheric mantle, asthenosphere, and an additional $6^{\text {th }}$ later of underplating. The Bouguer gravity anomaly produced by the model is shown on top.

Initial forward gravity modeling also manifested a considerable misfit of measured and calculated gravity which was interpreted as an underplated material (Section 3.3). The hypothesis of underplating in the area is not new. It was already suggested by Thybo and Artemieva (2013) and generally mentioned in the literature (Bogdanova et al., 2016, 2010; Mints et al., 2010). The recovered underplated body appears to be located on the north of the Tokmovo megablock under the Oka block (Fig. 1). The isostatic calculations are also showing the underplated body with an average thickness of ca. $10 \mathrm{~km}$ which is clearly outlined by the area of isostatic imbalance in the center of Volgo-Uralia (Fig. 9). Other regions with the major mass deficits are located on the south-east of the map and are related to the Pericaspian depression and South-Ural orogen. However, they do not correspond to any significant gravity misfit and are produced simply by the high deviation of the sedimentary and crustal thicknesses from the average values on the territory yielding higher values of mass imbalance. 


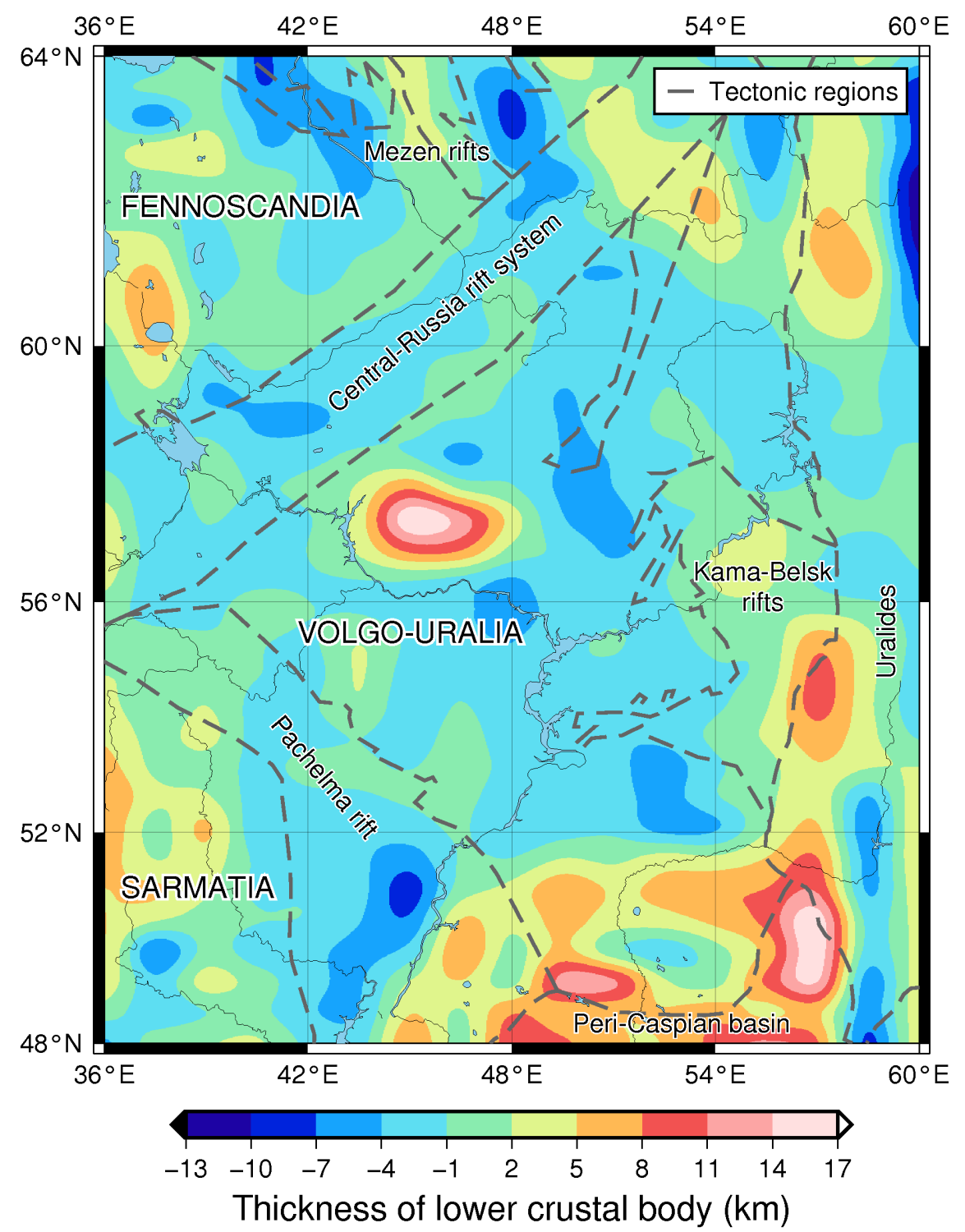

Figure 9: Thickness of the lower crustal body from the isostatic calculations.

The Moho depth of the developed IGMAS+ model shows a good agreement with seismic constraints (Fig. 10). The mean difference of seismic and modeled Moho is $1 \mathrm{~km}$, the standard deviation is $4.07 \mathrm{~km}$. This can be regarded as a satisfactory result as seismic Moho estimates usually are considered to have at least $2 \mathrm{~km}$ uncertainty (Ebbing et al., 2012). Therefore, at the end of the modeling, both seismic and gravity constraints were respected with the sufficient fit of measured and calculated gravity data. 


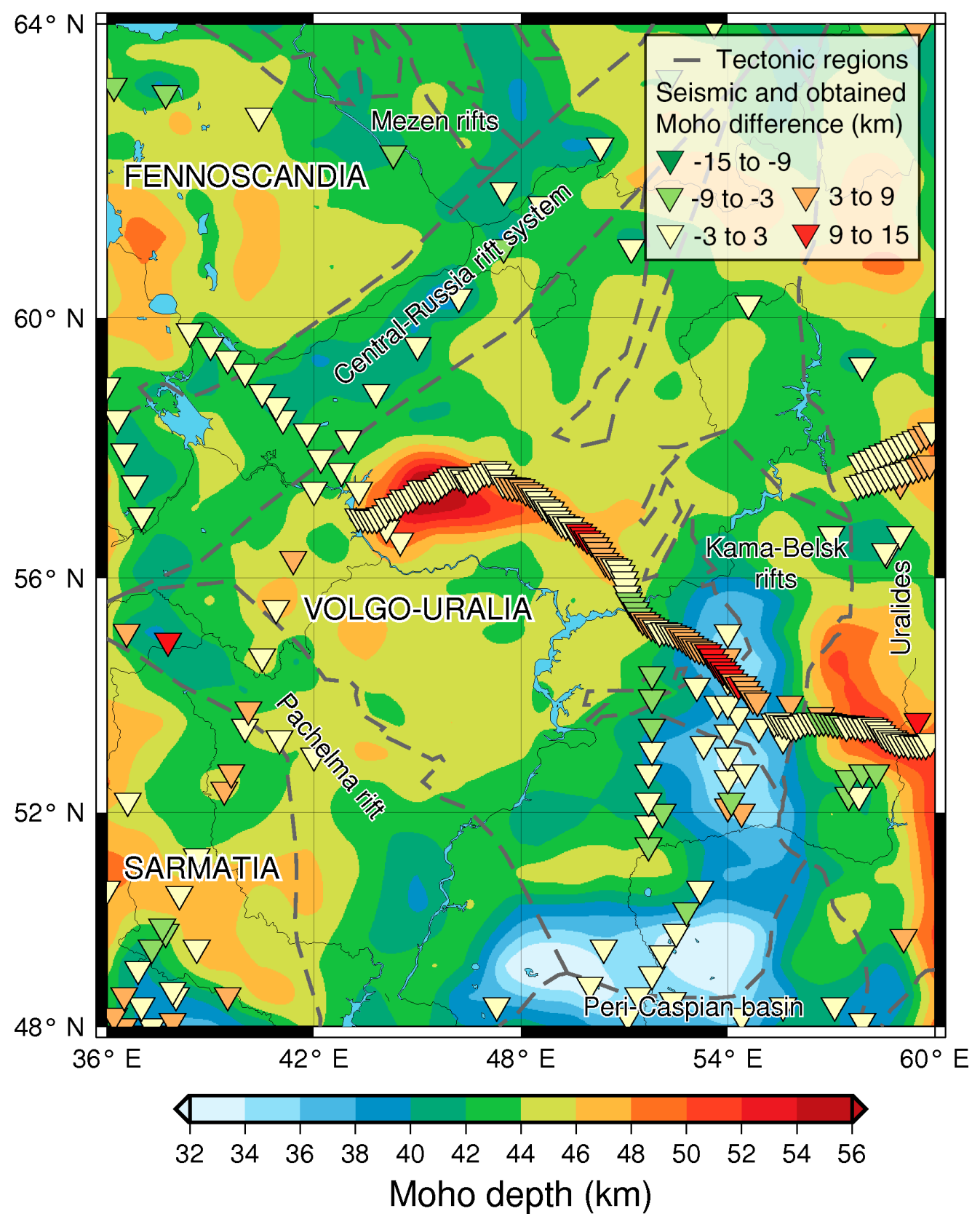

Figure 10: Moho model of Volgo-Uralian subcraton obtained through the gravity inversion with laterally variable density contrasts (Haas et al., 2020) and subsequent forward gravity modeling with seismic and gravity constraints in IGMAS+ (Götze and Lahmeyer, 1988; Schmidt et al., 2020). The difference between the model which was obtained in the process of gravity inversion and the IGMAS+ Moho model is shown in Figure $\mathrm{S} 2$ in the supplementary material.

Most of the differences between seismic data and the Moho model developed in IGMAS + are coming from the TATSEIS2003 seismic profile. The seismic Moho depth along the TATSEIS-2003 and URSEIS seismic profiles with respect to the 
https://doi.org/10.5194/se-2021-98

Preprint. Discussion started: 17 August 2021

(c) Author(s) 2021. CC BY 4.0 License.

model are shown in Fig. 11. As it is seen, within the TATSEIS profile seismic Moho has several steep troughs regarded as crustal roots (Artemieva and Thybo, 2013; Trofimov, 2006) which are not reflected in the satellite gravity field patterns. This case led us to a compromise solution: our Moho interface respects the main trends of Moho and at the same time smooths out its sharp gradients providing a closer fit to the gravity constraints.

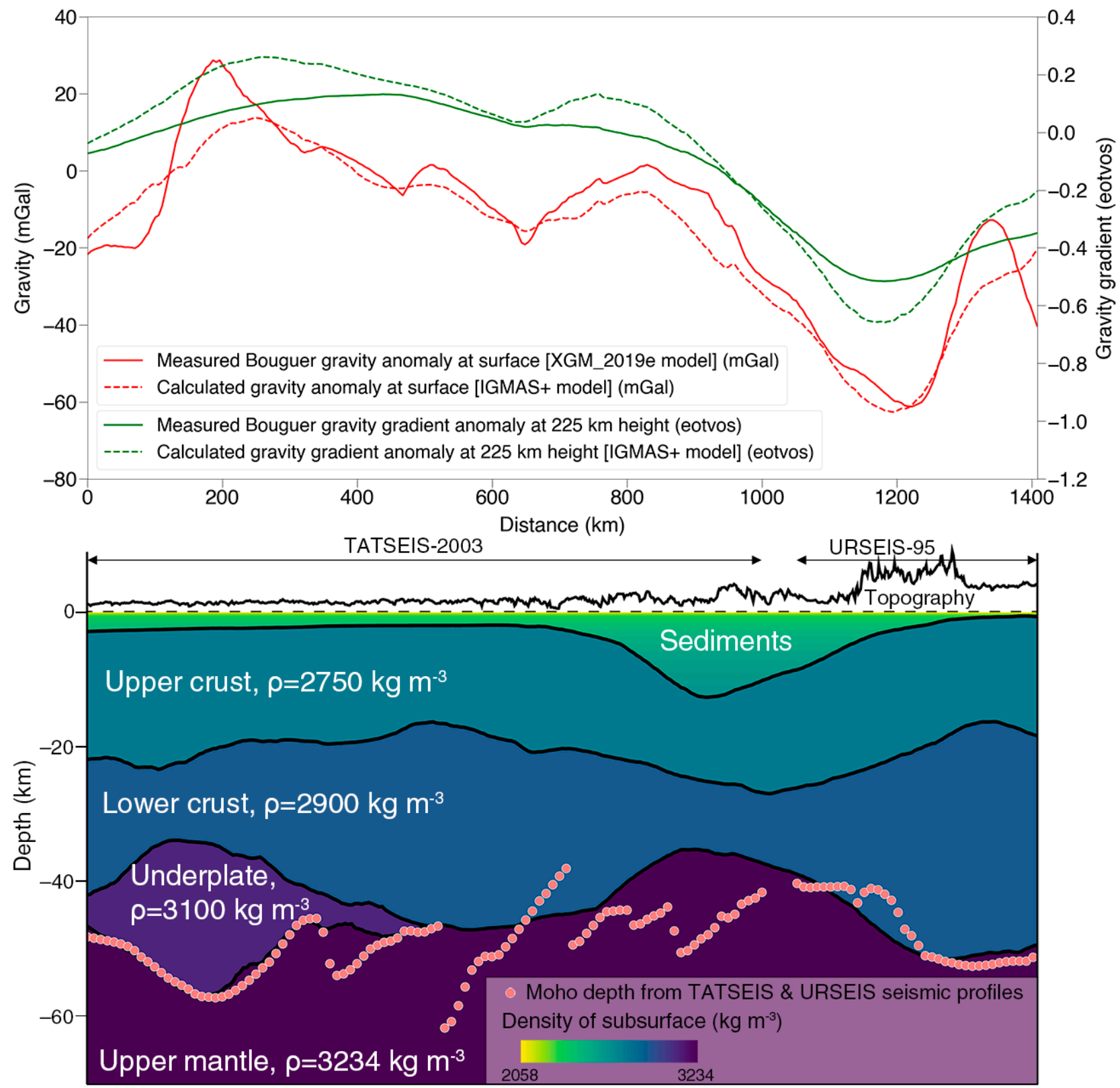

Figure 11: Measured and calculated Bouguer gravity and vertical gravity gradient anomalies from the crustal model (top) and

IGMAS+ model cross-section along TATSEIS-2003 and URSEIS-95 deep reflection profiles (bottom) - see figure 3 for the reference on the map. Subsurface is vertically exaggerated by the factor of 10 and topography is by the factor of 100 . 
https://doi.org/10.5194/se-2021-98

Preprint. Discussion started: 17 August 2021

(c) Author(s) 2021. CC BY 4.0 License.

(c) (1)

The IGMAS+ model showed crustal thickness variation from 32 to more than $55 \mathrm{~km}$ in some areas. The thinnest crust with thickness below $40 \mathrm{~km}$ appeared on the Pericaspian basin and Pre-Urals foredeep which correspond to the thickest sedimentary columns. A relatively thin crust was also found along the central Russia rift system as well as in the north and south parts of the Pachelma rift. In the axial parts of both rifts, the thickness of the crust shrinks down to 40-42 km, whilst on the surrounding territory, the crust gains its thickness back up to $44-46 \mathrm{~km}$. Thick crust is located underneath the Ural Mountains as well as in the center of the Volga-Uralian subcraton. In each domain, crustal thickness exceeds $50 \mathrm{~km}$. Overall, the developed model shows that Archean cratonic blocks are related to the thickening of the crust and Paleoproterozoic rifts are related to its thinning.

\section{4.3 Comparison of the developed model to other regional Moho models}

The resulting Moho model developed in IGMAS+ was cross-compared with the existing global and regional models which cover the studied region. For the comparison CRUST 1.0 global model (Laske et al., 2013), gravity-based GEMMA global model (Reguzzoni and Sampietro, 2015), and regional seismic EUNAseis model (Artemieva and Thybo, 2013) were selected. The difference between our model and the ones mentioned above is given in Fig. 12. It is clearly seen that the presented model 370 is much deeper than GEMMA, and it has more similar depths to CRUST 1.0 and EUNAseis models. This is explained by the fact that our model as well as the CRUST 1.0 and especially seismic-only EUNAseis model are better constrained by the available seismic observations compared to the gravity-based GEMMA model. 
https://doi.org/10.5194/se-2021-98

Preprint. Discussion started: 17 August 2021

(c) Author(s) 2021. CC BY 4.0 License.

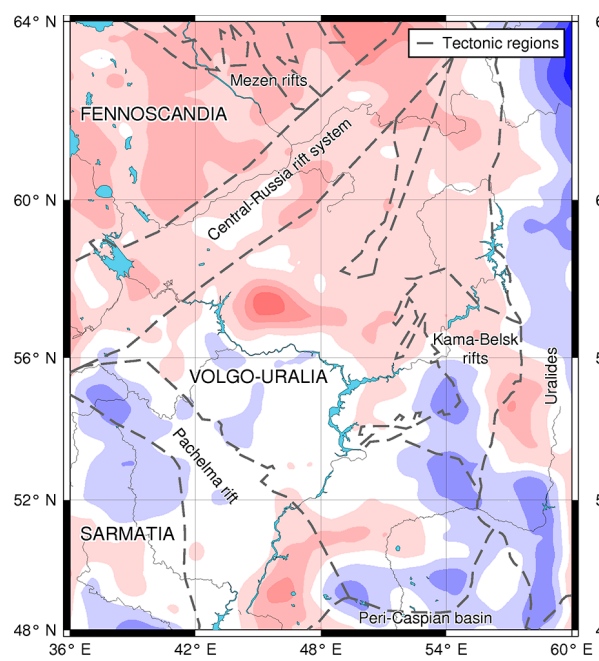

(a)

$\begin{array}{llllllllllllll}-13 & -10 & -7 & -4 & -1 & 2 & 5 & 8 & 11 & 14 & 17 & 20 & 23\end{array}$ Moho depth difference [current study - CRUST 1.0] (km)

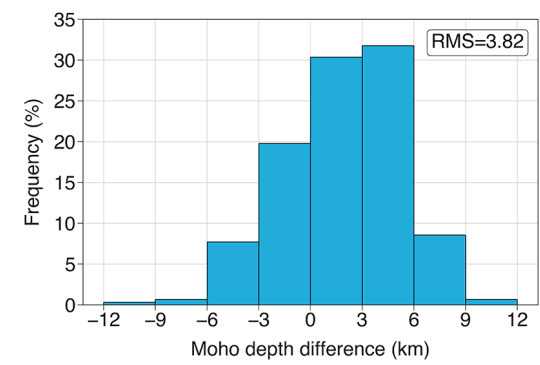

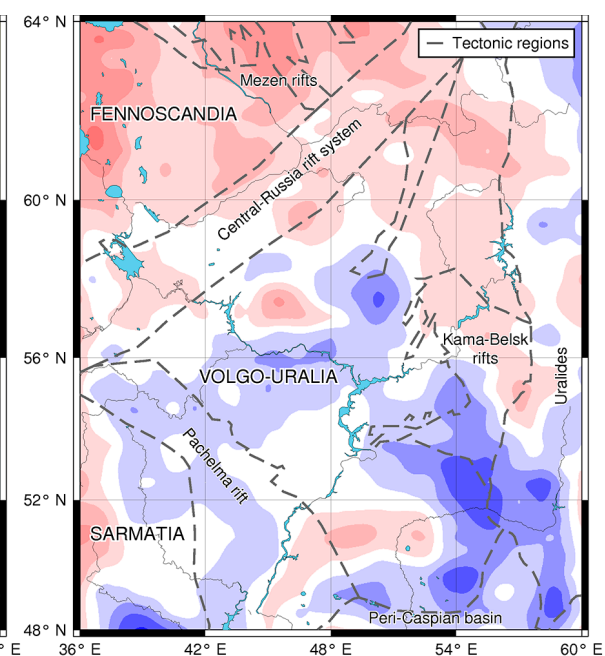

(b)

$\begin{array}{llllllllllllll}-13 & -10 & -7 & -4 & -1 & 2 & 5 & 8 & 11 & 14 & 17 & 20 & 23\end{array}$ Moho depth difference [current study - EUNAseis] (km)

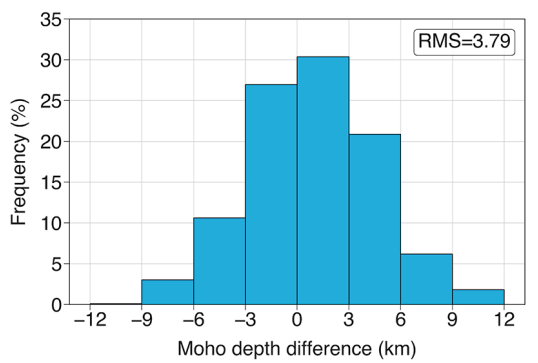

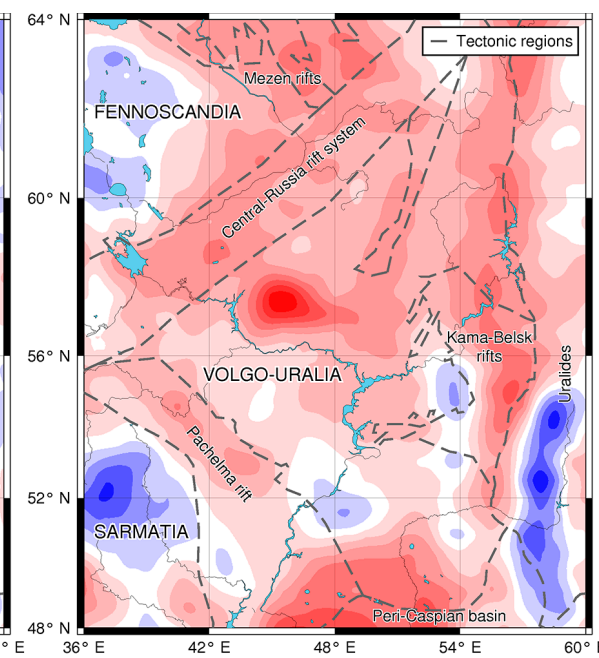

(c)

$\begin{array}{llllllllllllll}-13 & -10 & -7 & -4 & -1 & 2 & 5 & 8 & 11 & 14 & 17 & 20 & 23\end{array}$ Moho depth difference [current study - GEMMA] (km)

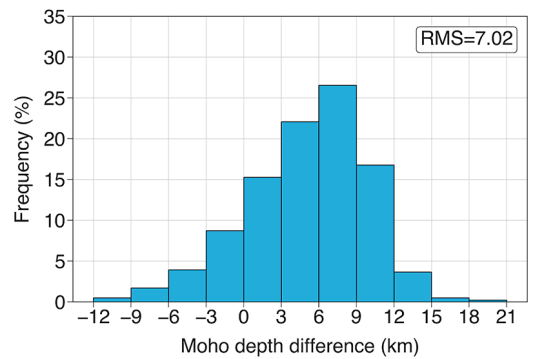

Figure 12: Difference in Moho depths between (a) obtained model developed in IGMAS+ and CRUST 1.0 model by Laske et al. (2013), (b) EUNAseis model by Artemieva and Thybo (2013), and (c) GEMMA model by Reguzzoni and Sampietro (2015). The top panel shows the maps of Moho depth residuals calculated as depth to Moho of the current study minus depth to Moho from the selected models in $\mathrm{km}$. The bottom panel shows histograms of Moho depths differences in $\mathbf{k m}$.

When comparing our model to EUNAseis and CRUST 1.0, it becomes obvious that the obtained model is relatively deeper on the north-western part of the territory which corresponds to Fennoscandia. One of the possible explanations for this feature is that the south-western part of Fennoscandia has relatively sparse coverage with seismic stations. This could have led to the discrepancy of the Moho depth on this zone estimated by gravity and seismic-based methods. As a result, the model developed during this study and GEMMA gravity-based model show 5-10 km deeper Moho for south-western Fennoscandia compared to CRUST 1.0 and EUNAseis.

Another significant difference that is seen between our model and CRUST 1.0 is the thicker crust in the center of Volgo-Uralia in our model where the underplated body is recovered. Most probably, this difference has been revealed because the most recent seismic investigations on the Russian platform including the TATSEIS profile were not used in the compilation of CRUST 1.0. One can see that the EUNAseis model which has an extensive seismic database for the Russian platform is much closer to our model in the center of Volgo-Uralia. 
https://doi.org/10.5194/se-2021-98

Preprint. Discussion started: 17 August 2021

(c) Author(s) 2021. CC BY 4.0 License.

(c) (i)

The last conspicuous feature which is worth mentioning is the shallower Moho of the obtained model on the south-east of Volgo-Uralia as opposed to the EUNAseis model. Such anomaly arises because USGS seismic catalog and EUNAseis seismic database have been built independently and have considerable differences in seismic Moho estimations in this region. Our model respects the seismic estimates of Moho depth given by the USGS catalog on the south-east of Volgo-Uralia (Fig. 10) but diverges from EUNAseis Moho estimations showing 3-9 km shallower Moho in the south-eastern part of Volgo-Uralia and south of Ural Mountains.

\section{Conclusions}

We presented a new crustal model of the Volga-Uralian subcraton obtained through gravity inversion and thorough forward gravity modeling with seismic constraints.

400 The gravity inversion was performed using laterally variable crust-mantle density contrasts. Two different density contrasts were estimated: $400 \mathrm{~kg} \mathrm{~m}^{-3}$ for Paleoproterozoic rifts and $550 \mathrm{~kg} \mathrm{~m}^{-3}$ for Archean cratons and Uralides. Reference Moho depth was equal to $45 \mathrm{~km}$. As the result, we retrieved a gravity-inverted Moho depth of Volgo-Uralia. The gravity-inverted Moho model already exposed the major patterns of the crustal thickness in the area and was used as a preliminary layer in further 3D modeling.

405 Gravity field inversion was followed by 3D forward gravity modeling performed in IGMAS+ software. Here, additionally to gravity-inverted Moho, sedimentary, crustal, upper mantle, and asthenospheric layers were included in the model. Seismic estimates of the Moho depth, as well as the Bouguer gravity anomalies from the XGM2019e gravity field model and topographically-corrected GOCE gravity gradients served as the main constraints for the modeling. The 3D forward gravity modeling revealed a considerable gravity misfit in the central part of the study area. We interpreted this misfit as an underplated

410 body which is supported by the isostatic calculations. This reinforces the hypotheses of an underplated body located on the top of the Moho beneath the Oka block of Volgo-Uralia (Thybo and Artemieva, 2013).

The final crustal model respects all the main geological features of the Volga-Uralian subcraton and its surroundings with Moho thickening in the cratons and under the Ural Mountains and thinning along the Paleoproterozoic rifts, Pericaspian sedimentary basin, and Pre-Urals foredeep. The obtained crustal model will serve as a basis for further basin analysis and

415 geothermal modeling.

\section{Code and data availability}

The code of Haas et al. (2020) for the gravity inversion with laterally variable density contrasts is available at https://github.com/peterH105/Gradient_Inversion. The data used in this study is available at https://doi.org/10.5281/zenodo.5148173 (Ognev et al., 2021). Figures and maps were plotted using ArcGIS Pro and Python with Matplotlib and PyGMT packages. 
https://doi.org/10.5194/se-2021-98

Preprint. Discussion started: 17 August 2021

(c) Author(s) 2021. CC BY 4.0 License.

(c) (i)

\section{Author contributions}

IO and JE designed the study. IO accumulated and processed the data, performed gravity field inversion, built the crustal model in IGMAS+, and visualized the results. JE supervised the work. PH wrote and shared the initial code for gravity inversion with laterally variable density contrasts. All the authors interpreted the results. All the authors contributed to the manuscript writing either by directly formulating text or giving feedback on figures or specific chapters.

\section{Competing interests}

The authors declare that they have no conflict of interest.

\section{Acknowledgments}

The presented work has been supported by the German academic exchange service (DAAD) and by the Ministry of Science

430 and Higher Education of the Russian Federation under agreement No. 075-15-2020-931 within the framework of the development program for a world-class Research Center "Efficient development of the global liquid hydrocarbon reserves".

\section{References}

Aitken, A. R. A., Salmon, M. L., and Kennett, B. L. N.: Australia's Moho: A test of the usefulness of gravity modelling for the determination of Moho depth, Tectonophysics, 609, 468-479, https://doi.org/10.1016/j.tecto.2012.06.049, 2013.

435 Amante, C. and Eakins, B. W.: 1 Arc-Minute Global Relief Model: Procedures, Data Sources and Analysis, $24,2009$.

Artemieva, I. M.: Dynamic topography of the East European craton: Shedding light upon lithospheric structure, composition and mantle dynamics, Global and Planetary Change, 58, 411-434, https://doi.org/10.1016/j.gloplacha.2007.02.013, 2007.

Artemieva, I. M.: Lithosphere structure in Europe from thermal isostasy, Earth-Science Reviews, 188, 454-468, https://doi.org/10.1016/j.earscirev.2018.11.004, 2019.

440 Artemieva, I. M. and Thybo, H.: EUNAseis: A seismic model for Moho and crustal structure in Europe, Greenland, and the North Atlantic region, Tectonophysics, 609, 97-153, https://doi.org/10.1016/j.tecto.2013.08.004, 2013.

Beardsmore, G. R. and Cull, J. P.: Crustal Heat Flow: A Guide to Measurement and Modelling, 1st ed., Cambridge University Press, https://doi.org/10.1017/CBO9780511606021, 2001.

Bogdanova, S. V., De Waele, B., Bibikova, E. V., Belousova, E. A., Postnikov, A. V., Fedotova, A. A., and Popova, L. P.: 445 Volgo-Uralia: The first U-Pb, Lu-Hf and Sm-Nd isotopic evidence of preserved Paleoarchean crust, American Journal of Science, 310, 1345-1383, https://doi.org/10.2475/10.2010.06, 2010. 
https://doi.org/10.5194/se-2021-98

Preprint. Discussion started: 17 August 2021

(c) Author(s) 2021. CC BY 4.0 License.

(c) (i)

Bogdanova, S. V., Gorbatschev, R., and Garetsky, R. G.: EUROPE|East European Craton Systems and Environmental Sciences, Elsevier, B978012409548910020X, https://doi.org/10.1016/B978-0-12-4095489.10020-X, 2016.

450 Bouman, J., Ebbing, J., Meekes, S., Abdul Fattah, R., Fuchs, M., Gradmann, S., Haagmans, R., Lieb, V., Schmidt, M., Dettmering, D., and Bosch, W.: GOCE gravity gradient data for lithospheric modeling, International Journal of Applied Earth Observation and Geoinformation, 35, 16-30, https://doi.org/10.1016/j.jag.2013.11.001, 2015.

Bouman, J., Ebbing, J., Fuchs, M., Sebera, J., Lieb, V., Szwillus, W., Haagmans, R., and Novak, P.: Satellite gravity gradient grids for geophysics, Sci Rep, 6, 21050, https://doi.org/10.1038/srep21050, 2016.

455 Brown, D., Juhlin, C., Tryggvason, A., Steer, D., Ayarza, P., Beckholmen, M., Rybalka, A., and Bliznetsov, M.: The crustal architecture of the Southern and Middle Urals from the URSEIS, ESRU, and Alapaev reflection seismic surveys, in: Mountain Building in the Uralides: Pangea to the Present, Geophysical Monograph 132, 17, 2002.

Chulick, G. S., Mooney, W. D., and Detweiler, S.: CRUST’02: a new global model, in: AGU Fall Meeting Abstracts, 2002.

Chulick, G. S., Detweiler, S., and Mooney, W. D.: Seismic structure of the crust and uppermost mantle of South America and surrounding oceanic basins, 42, 260-276, https://doi.org/10.1016/j.jsames.2012.06.002, 2013.

Ebbing, J.: Isostatic density modelling explains the missing root of the Scandes, 87, 13-20, 2007.

Ebbing, J., England, R. W., Korja, T., Lauritsen, T., Olesen, O., Stratford, W., and Weidle, C.: Structure of the Scandes lithosphere from surface to depth, Tectonophysics, 536-537, 1-24, https://doi.org/10.1016/j.tecto.2012.02.016, 2012.

Eshagh, M., Hussain, M., Tenzer, R., and Romeshkani, M.: Moho Density Contrast in Central Eurasia from GOCE Gravity

Gradients, 19, 2016.

Gorbatschev, R. and Bogdanova, S.: Frontiers in the Baltic Shield, Precambrian Research, 64, 3-21, https://doi.org/10.1016/0301-9268(93)90066-B, 1993.

Götze, H. J. and Lahmeyer, B.: Application of three-dimensional interactive modeling in gravity and magnetics, 53, 1096$1108,1988$.

470 Haas, P., Ebbing, J., and Szwillus, W.: Sensitivity analysis of gravity gradient inversion of the Moho depth-a case example for the Amazonian Craton, 221, 1896-1912, https://doi.org/10.1093/gji/ggaa122, 2020.

Hantschel, T. and Kauerauf, A. I.: Fundamentals of basin and petroleum systems modeling, Springer, Dordrecht; New York, 476 pp., 2009.

Kaban, M. K., Schwintzer, P., Artemieva, I. M., and Mooney, W. D.: Density of the continental roots: compositional and

thermal contributions, Earth and Planetary Science Letters, 209, 53-69, https://doi.org/10.1016/S0012-821X(03)00072-4, 2003.

Khasanov, R. R., Gafurov, S. Z., and Rakhimzyanov, A. I.: The degree of the epigenetic transformation of an organic matter in the Early Carboniferous sediments of the central part of the Volga-Ural oil and gas province (in Russian), 29-31, 2016.

Khristoforova, N. N., Khristoforov, A. V., and Bergemann, M. A.: Analysis of geothermal maps and petroleum potential of deep sediments, 10-12, 2008. 
https://doi.org/10.5194/se-2021-98

Preprint. Discussion started: 17 August 2021

(c) Author(s) 2021. CC BY 4.0 License.

Laske, G., Masters, G., Ma, Z., and Pasyanos, M.: Update on CRUST1.0 - A 1-degree Global Model of Earth's Crust, in: Geophysical Research Abstracts, EGU2013-2658, 2013.

Mints, M. V., Suleimanov, A. K., Babayants, P. S., Belousova, E. A., Blokh, Yu. I., Bogina, M. M., Bush, V. A., Dokukin, K. A., Zamozhnaya, N. G., Zlobin, V. L., Kaulina, T. V., Konilov, A. N., Mikhailov, V. O., Natapov, L. M., Piip, V. B., Stupak, 485 V. M., Tikhotsky, S. A., Trusov, A. A., Filippova, I. B., and Shur, D. Yu.: Deep structure, evolution and minerals of the Early Precambrian basement of the East European Platform: Interpretation of materials on the reference profile 1-EU, profiles 4B and TATSEIS (in Russian), GEOKART: GEOS., Moscow, 2010.

Mints, M. V., Suleimanov, A. K., Zamozhniaya, N. G., and Stupak, V. M.: 12. Study of the basement of the Russian European Platform based on a system of geotraverses and CMP profiles: 3D models of the Early Precambrian crust in key regions, in:

490 Geological Society of America Special Papers, vol. 510, Geological Society of America, 265-300, https://doi.org/10.1130/2015.2510(12), 2015.

Neprochnov, Yu. P., Kosminskaya, I. P., and Malovitsky, Ya. P.: Structure of the crust and upper mantle of the Black and Caspian Seas, Tectonophysics, 10, 517-538, https://doi.org/10.1016/0040-1951(70)90042-9, 1970.

Ognev, I., Ebbing, J., and Haas, P.: Crustal structure of the Volgo-Uralian subcraton revealed by inverse and forward gravity modeling [dataset] (0.3), https://doi.org/10.5281/ZENODO.5148173, 2021.

Puchkov, V. N.: Geology of the Urals and Cisurals (topical issues of stratigraphy tectonics, geodynamics and metallogeny), DesignPoligrafService (in Russian), 2010.

Rabbel, W., Kaban, M., and Tesauro, M.: Contrasts of seismic velocity, density and strength across the Moho, Tectonophysics, 609, 437-455, https://doi.org/10.1016/j.tecto.2013.06.020, 2013.

500 Reguzzoni, M. and Sampietro, D.: GEMMA: An Earth crustal model based on GOCE satellite data, International Journal of Applied Earth Observation and Geoinformation, 35, 31-43, https://doi.org/10.1016/j.jag.2014.04.002, 2015.

Rybalka, A. V., Petrov, G. A., Kashubin, S. N., and Yukhlin, K.: Middle Ural transect ESRU, in: Structure and Dynamics of the Lithosphere of Eastern Europe. Results of Studies under the EUROPROBE Programme (in Russian), GEOKART, GEOS, Moscow, 390-402, 2006.

505 Schmidt, S., Anikiev, D., Götze, H.-J., Gomez Garcia, À., Gomez Dacal, M. L., Meeßen, C., Plonka, C., Rodriguez Piceda, C., Spooner, C., and Scheck-Wenderoth, M.: IGMAS+ - a tool for interdisciplinary 3D potential field modelling of complex geological structures., in: EGU General Assembly Conference Abstracts, 8383, https://doi.org/10.5194/egusphere-egu20208383, 2020.

Shargorodskiy, I. E., Liberman, V. B., Kazakov, E. R., Zinatova, M. F., Girina, I. N., and Ziganshin, A. A.: Construction of tectonic scheme of the Volga Federal district central regions (in Russian), 12-15, 2004.

Sobh, M., Ebbing, J., Mansi, A. H., and Götze, H.-J.: Inverse and 3D forward gravity modelling for the estimation of the crustal thickness of Egypt, Tectonophysics, 752, 52-67, https://doi.org/10.1016/j.tecto.2018.12.002, 2019.

Steffen, R., Strykowski, G., and Lund, B.: High-resolution Moho model for Greenland from EIGEN-6C4 gravity data, Tectonophysics, 706-707, 206-220, https://doi.org/10.1016/j.tecto.2017.04.014, 2017.

515 Thouvenot, F., Kashubin, S. N., Poupinet, G., Makovskiy, V. V., Kashubina, T. V., Matte, Ph., and Jenatton, L.: The root of the Urals: evidence from wide-angle reflection seismics, Tectonophysics, 250, 1-13, https://doi.org/10.1016/00401951(95)00058-8, 1995. 
https://doi.org/10.5194/se-2021-98

Preprint. Discussion started: 17 August 2021

(C) Author(s) 2021. CC BY 4.0 License.

Thybo, H. and Artemieva, I. M.: Moho and magmatic underplating in continental lithosphere, Tectonophysics, 609, 605-619, https://doi.org/10.1016/j.tecto.2013.05.032, 2013.

520 Trofimov, V. A.: Deep CMP seismic surveying along the Tatseis-2003 geotraverse across the Volga-Ural petroliferous province, 40, 14, 2006.

Tryggvason, A., Brown, D., and Pérez-Estaún, A.: Crustal architecture of the southern Uralides from true amplitude processing of the Urals Seismic Experiment and Integrated Studies (URSEIS) vibroseis profile, Tectonics, 20, 1040-1052, https://doi.org/10.1029/2001TC900020, 2001.

525 Uieda, L., Barbosa, V. C. F., and Braitenberg, C.: Tesseroids: Forward-modeling gravitational fields in spherical coordinates, GEOPHYSICS, 81, F41-F48, https://doi.org/10.1190/geo2015-0204.1, 2016.

Zingerle, P., Pail, R., Gruber, T., and Oikonomidou, X.: The experimental gravity field model XGM2019e, GFZ Data Services, 2019. 